\title{
A Chemical Investigation of the Fruit Bodies of Lepista nebularis
}

\author{
Zijie Pang, ${ }^{a}$ Heidrun Anke ${ }^{b}$ and Olov Sterner ${ }^{a}$
}

${ }^{\mathrm{a}}$ Division of Organic Chemistry 2, Chemical Center, University of Lund, P.O.B. 124, S-221 00 Lund, Sweden and ${ }^{\mathrm{b}}$ Department of Biotechnology, University of Kaiserslautern, Paul Ehrlichstr. 23, D-67663 Kaiserslautern, Germany

\begin{abstract}
Pang, Z., Anke, H. and Sterner, O., 1994. A Chemical Investigation of the Fruit Bodies of Lepista nebularis. - Acta Chem. Scand. 48: 408-410 @ Acta Chemica Scandinavica 1994.

An investigation of the metabolites present in the intact fruit bodies and those formed as a response to injury of the fruit bodies of Lepista nebularis has been performed. In addition to unsaturated and hydroxylated fatty acids, the intact fruit bodies contain 2,4-diphenyl-2-butenal. The injured specimens also contained $(8 E)$ 10-hydroxy-8-decenoic acid and (8E)-10-oxo-8-decenoic acid, presumably formed enzymatically from (12Z)-9,10-dihydro $\wedge$-12-octadecenoic acid, as well as small amounts of 4-hydroxy-2.4-diphenyl-2-butenal. 2.4-Dipheny-2-butenal possess weak to intermediate antimicrobial and cytotoxic activities, and it is possible that the $\alpha, \beta$-unsaturated aldehydes are responsible for the gastric upsets that may strike consumers of this mushroom.
\end{abstract}

Fruit bodies of Lepista nebularis (= Clitocybe nebularis) (clouded agaric) are considered to be edible, although they may cause indisposition to some consumers. ${ }^{1}$ Although they are frequently attacked by diptera larvae, the fruit bodies of Lepista nebularis appear to be less sensitive to the most common pest of fungi (Mycetophila fungorum $),{ }^{2}$ and this could be due to the presence of protective secondary metabolites. As nothing appears to be known about the metabolites of $L$. nebularis, we have performed a chemical investigation of this species. In order to study whether any metabolites are formed in the fruit bodies as a response to injury, as is the case in several other species, ${ }^{3,4}$ we have compared the contents of ethyl acetate extracts of fresh, intact mushrooms with extracts of mushrooms that had been ground in a meat grinder (to induce injury) $15 \mathrm{~min}$ prior to extraction. TLC and GC-MS analyses of the extracts showed significant differences between the extracts, and the major compounds were isolated.

\section{Result and discussion}

The compounds present in the largest amounts both in the extracts of intact as well as injured fruit bodies are fatty acids, especially linoleic acid. From the extracts of the injured specimens only, (12Z)-9,10-dihydroxy-12-octadecenoic acid (1) was obtained in significant amounts (20 mg from $300 \mathrm{~g}$ fresh fruit bodies) (Fig. 1). This compound has previously been isolated from the rice plant and has been suggested to be a defensive metabolite that<smiles>CCCCC/C=C/CC(O)C(O)CCCCCCCC(=O)O</smiles>

1<smiles>[R]C=CCCCCCCC(=O)O</smiles><smiles>O=CC(=CCc1ccccc1)c1ccccc1</smiles>

5<smiles>O=C/C(=C/C(O)c1ccccc1)c1ccccc1</smiles>

6

Fig. 1.

protects the plant against the rice blast disease. ${ }^{5}$ It may well be a precursor to the short fatty acids $(8 E)$-10-hydroxy-8-decenoic acid (2) and (8E)-10-oxo-8-decenoic 
acid (3) that were also obtained from the extract of the injured specimens (30 and $9 \mathrm{mg}$, respectively, from $300 \mathrm{~g}$ fresh fruit bodies). Hydroxylated and/or unsaturated fatty acids surprisingly often possess biological activities, for instance antifungal ${ }^{6}$ and nematicidal ${ }^{7,8}$ activities, and their presence in fruit bodies may well have a biological significance. Recently $(E)$-2-decenedioic acid (4) was isolated as a nematicidal principle of Pleurotus ostreatus, ${ }^{9}$ a fungus the hyphae of which are known to be able to paralyse, penetrate and digest nematodes. ${ }^{10}$ It was also shown that short fatty acids $(\mathrm{C} 8-\mathrm{C} 12)$ are potent nematicidal agents. ${ }^{9}$ The formation of $(8 E)$-10-hydroxy-8-decenoic acid (2) and (8E)-10-oxo-8-decenoic acid (3) has previously been demonstrated in the injured fruit bodies of Agaricus campestris. ${ }^{11}$ Compound 3 stimulates the mycelial growth and stipe elongation in Agaricus bisporus, and has been suggested to be a mushroom hormone involved in the fruiting of this species. ${ }^{12}(8 E)$-10-Hydroxy8 -decenoic acid (2) has previously been isolated from the fruit bodies of Cantharellus tubaeformis, ${ }^{3}$ and its biological activities are presently being investigated. In addition, ergosterol and ergosterol peroxide could also be isolated from both types of extract. The former, being the major steroid in fungal membranes, has been found in virtually all fungal species that we have investigated, while it is quite seldom that we have obtained the latter.

2,4-Diphenyl-2-butenal (5) was isolated from extracts of both intact and injured mushrooms, while its hydroxylated derivative 6 only could be detected in the extract of the injured specimens. The amounts of 4-hydroxy-2,4diphenyl-2-butenal (6) obtained are small, but both compounds give a very distinctly coloured spot when the TLC plates were developed with anisaldehyde-sulfuric acid, so we feel confident that compound $\mathbf{6}$ is formed in the injured fruit bodies. If compound $\mathbf{5}$ is the precursor, which is likely, the oxidation is probably enzymatic as, at no time, did we observe any traces of compound $\mathbf{6}$ during the handling of compound $\mathbf{5}$. The structures of the compounds were determined by NMR and mass spectroscopy. The stereochemistry of the C-2/C-3 double bond was established based on the strong NOESY correlation observed between $1-\mathrm{H}$ and $3-\mathrm{H}$ in the spectrum of 2,4diphenyl-2-butenal (5), and the enhancement of the signal for $1-\mathrm{H}(10 \%)$ when $3-\mathrm{H}$ was irradiated and $3-\mathrm{H}(12 \%)$ when 1-H was irradiated for 4-hydroxy-2,4-diphenyl-2butenal (6). 2,4-Diphenyl-2-butenal (5) has previously been prepared synthetically, ${ }^{13,14}$ but is not known as a natural product. 4-Hydroxy-2,4-diphenyl-2-butenal (6) is a new compound. The spectroscopic data were not given ${ }^{13,14}$ for compound $\mathbf{5}$, and a full set is therefore given in the Experimental. Both compounds 5 and $\mathbf{6}$ are suspect from a toxicological point of view; the $\alpha, \beta$-unsaturated aldehyde functionality is electrophilic and it is possible that the compounds are responsible for the gastric upsets that may strike consumers. ${ }^{1}$ When 2,4-diphenylbutenal (5) was assayed for biological activities, it was found to possess weak antifungal and antibacterial (Gram positive bacteria) activities. The minimal inhibi- tory concentration was for example $20 \mu \mathrm{g}$ per $\mathrm{ml}$ for Paecilomyces varioti, and $50 \mu \mathrm{g}$ per $\mathrm{ml}$ for Mucor miehei, Bacillus subtilis and Bacillus brevis. No phytotoxic effect towards Setaria italica and Lepidium sativum could be noted. Its cytotoxic activity towards L1210 cells (lymphocytic leukemia mouse) was intermediate, $25 \mu \mathrm{g}$ per $\mathrm{ml}$ lysed all cells. The cytotoxic activity of 4-hydroxy-2,4diphenylbutenal (6) was weaker, $50 \mu \mathrm{g}$ per $\mathrm{ml}$ did not lyse the cells. Owing to the small amounts available no other assays were performed with this compound.

The GC-MS analysis showed that various isomers of octanol and octenol are present in the extracts of the injured specimens, these are probably co-produced with the $\mathrm{C}_{10}$ fatty acids by the oxidation of $\mathrm{C}_{18}$ fatty acids. In addition, the presence of 2-benzylethanol and 2-benzylethanal in the extracts is noted, and it is possible that 2,4-diphenylbutenal (5) is formed from the latter.

\section{Experimental}

Fruit bodies of Lepista nebularis (Fr.) Harmaja were collected in the vicinity of the University of Kaiserslautern, and extracted the same day. Some specimens were ground in a meat grinder together with ethyl acetate (2 l per $\mathrm{kg}$ fruit bodies), in order to investigate the original contents, while others were ground without solvent and left as a mush for 15 min before being extracted with ethyl acetate. The extracts were compared by TLC and GC-MS analyses, and the pure compounds were isolated by chromatography on $\mathrm{SiO}_{2}$ columns eluted with different mixtures of ethyl acetate and heptane. The NMR spectra were recorded with a Bruker ARX500 spectrometer in $\mathrm{CDCl}_{3}$ with the solvent signal as reference (7.255 ppm for ${ }^{1} \mathrm{H}$ NMR and $77.1 \mathrm{ppm}$ for ${ }^{13} \mathrm{C}$ NMR). Coupling constants are given in $\mathrm{Hz}$. The UV spectra were recorded with a Cary 219, the IR spectra with a Perkin Elmer 257, and the mass spectra with a Jeol SX102 spectrometer. The biological assays were performed as described in Ref. 15.

(2E)-2,4-Diphenyl-2-butenal (5) was obtained as an oil ( $3.5 \mathrm{mg}$ from $300 \mathrm{~g}$ fresh fruit bodies). MS (EI, $70 \mathrm{eV}$ ), $m / z: 222.1018\left(M^{+}, 100 \%, \mathrm{C}_{16} \mathrm{H}_{14} \mathrm{O}\right.$ requires 222.1044$)$, $204(14 \%), 178$ (19), 115 (46), 103 (30) and $91(31) .{ }^{1} \mathrm{H}$ NMR: $\delta 9.66(\mathrm{~s}, 1-\mathrm{H}), 7.42\left(\mathrm{dd}, J=7\right.$ and $7,3^{\prime \prime}-\mathrm{H}$ and $\left.5^{\prime \prime}-\mathrm{H}\right), 7.38\left(\mathrm{~m}, 4^{\prime \prime}-\mathrm{H}\right), 7.32$ (dd, $J=7$ and $7,3^{\prime}-\mathrm{H}$ and $\left.5^{\prime}-\mathrm{H}\right), 7.25\left(\mathrm{~m}, 4^{\prime}-\mathrm{H}\right), 7.23$ (d, $J=7,2^{\prime \prime}-\mathrm{H}$ and $\left.6^{\prime \prime}-\mathrm{H}\right)$, $7.16\left(\mathrm{~d}, J=7,2^{\prime}-\mathrm{H}\right.$ and $\left.6^{\prime}-\mathrm{H}\right), 6.87\left(\mathrm{t}, J_{3,4}=7.6,3-\mathrm{H}\right)$, $3.69\left(\mathrm{~d}, J_{3,4}=7.6,4-\mathrm{H}_{2}\right) .{ }^{13} \mathrm{C}$ NMR: $\delta 193.5(\mathrm{C}-1), 153.4$ (C-3), 144.2, 138.1 and 132.2 (C-2, C-1' and C-1" ${ }^{\prime \prime}$, 129.5, 128.9, 128.5 and 128.4 (C-2', C-3', C-5', C-6', $\mathrm{C}-2^{\prime \prime}, \mathrm{C}-3^{\prime \prime}, \mathrm{C}-5^{\prime \prime}$ and C-6"), 128.2 and 126.8 (C-4' and C-4"), 35.8 (C-4). IR (KBr): 1695,1500 and $710 \mathrm{~cm}^{-1}$. UV (ethanol) $\lambda_{\max }(\varepsilon): 255$ (5050) and $273 \mathrm{~nm}(2300)$.

(2E)-4-Hydroxy-2,4-diphenyl-2-butenal (6) was obtained as an oil $(0.5 \mathrm{mg}$ from $300 \mathrm{~g}$ fresh fruit bodies). MS (EI, $70 \mathrm{eV}), m / z: 238.1000\left(M^{+}, 59 \%, \mathrm{C}_{16} \mathrm{H}_{14} \mathrm{O}_{2}\right.$ requires 
238.0994), $209(71 \%), 191(31), 105$ (100), and 77 (49) ${ }^{1} \mathrm{H}$ NMR: $\delta 9.69(\mathrm{~s}, 1-\mathrm{H}), 7.45$ to $7.15(\mathrm{~m}, 10 \times \mathrm{ArH})$, $6.84\left(\mathrm{~d}, J_{3.4}=9.1,3-\mathrm{H}\right), 4.52\left(\mathrm{~d}, J_{3.4}=9,4-\mathrm{H}\right)$. UV (ethanol) $\lambda_{\max }(\varepsilon): 246(5500)$ and $273 \mathrm{~nm}$ (2300). Insufficient amounts were obtained for IR and ${ }^{13} \mathrm{C}$ NMR spectroscopy.

Acknowledgements. The authors thank Dr. Marc Stadler, University of Kaiserslautern, for identifying the fruit bodies. Financial support from the Swedish Natural Science Research Council is gratefully acknowledged.

\section{References}

1. Phillips, R. Mushrooms and Other Fungi of Great Britain and Europe, Pan, London 1981, p. 48.

2. Hackman, W. and Meinander, M. Ann. Zool. Fennici 16 (1979) 50 .

3. Pang, Z., Sterner, O. and Anke, H. Acta Chem. Scand. 46 (1992) 301.

4. Pang, Z. and Sterner, O. J. Org. Chem. 56 (1991) 1233.
5. Kato, T., Yamaguchi, Y., Uyehara, T., Yokoyama, T., Namai, T. and Yamanaka, S. Tetrahedron Lett. 24 (1983) 4715.

6. Kato, T., Yamaguchi, Y., Hirano, T., Yokoyama, T., Uyehara, T., Namai, T., Yamanaka, S. and Harada, N. Chem. Lett. (1984) 409.

7. Stadler, M., Mayer, A., Anke, H. and Sterner, O. Planta Med. (1993). In press.

8. Stadler, M., Anke, H. and Sterner, O. Arch. Microbiol. 160 (1993). In press.

9. Kwok, O. C. H., Plattner, R., Weisleder, D. and Wicklow, D. T. J. Chem. Ecol. 18 (1992) 127.

10. Barron, G. L. and Thorn, R. G. Can. J. Bot. 65 (1987) 774

11. Tressl, R., Bahri, D. and Engel, K.-H. J. Agric. Food Chem. 30 (1982) 89.

12. Mau, J.-L., Beelman, R. B. and Ziegler, G. R. Phytochemistry 31 (1992) 4059.

13. Treibs, W. and Krumbholtz, K. Chem. Ber. 85 (1952) 1116.

14. Blau, K., Burgemeister, I., Grasnick, J. and Voerckel, V. J. Prakt. Chem. 333 (1991) 455.

15. Erkel, G., Anke, T., Velten, R. and Steglich, W. Z. Naturforsch., Teil C 46 (1991) 442.

Received September 1, 1993. 